\title{
A landslide susceptibility assessment in urban areas based on existing data: an example from the Iguaná Valley, Medellín City, Colombia
}

\author{
J. Klimeš ${ }^{1}$ and V. Rios Escobar ${ }^{2}$ \\ ${ }^{1}$ Institute of Rock Structure and Mechanics, Czech Academy of Sciences, Prague, Czech Republic \\ ${ }^{2}$ Department of Physical Geography and Geoecology, Faculty of Science, Charles University, Prague, Czech Republic
}

Received: 20 March 2010 - Revised: 9 July 2010 - Accepted: 16 August 2010 - Published: 6 October 2010

\begin{abstract}
Fast urbanization and the morphological conditions of the Iguaná River Basin, Medellín, Colombia have forced many people to settle on landslide prone slopes as evidenced by extensive landslide induced damage. In this study we used existing disaster databases (inventories) in order to examine the spatial and temporal variability of landsliding within this watershed. The spatial variability of landsliding was examined using "expert-based" and "weighted" landslide susceptibility models. The constructed landslide susceptibility maps demonstrate consistent results irrespective of the underlying method. These show that at least 55.9\% of the watershed is highly or very highly susceptible to landsliding. In addition, the temporal distribution of landsliding was analyzed and compared with climatic data. Results show that the area has a distinct bimodal rainfall distribution, and it is clear that landsliding is particularly frequent during the later rainy season between October and November. Moreover, landslides are more common during La Niña years. It is recommended that the existing landslide inventories are improved so as to be of greater use in the future land use planning of the watershed. The construction of landslide susceptibility maps based on existing data represents a significant step towards landslide mitigation in the area. Using susceptibility and hazard assessment during the developmental process should lessen the need for disaster response at a later stage.
\end{abstract}

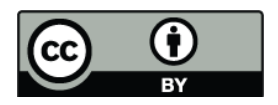

Correspondence to: J. Klimeš

(jklimes@centrum.cz)

\section{Introduction}

The population growth and increasing urbanization of areas prone to natural hazards worsen the impact of dangerous natural processes in developing as well as developed world (Rosenfeld, 1994; Alexander, 1995; Guzzetti et al., 1999). This trend is observed also in Colombia (Alcántara-Ayala, 2002; Nadim et al., 2006). Nearly $28 \%$ of Colombia is occupied by Andean mountain ranges. This area is the most densely populated region of Colombia with the majority of its urban centers including the city of Medellín with more than 3 million inhabitants. Located in the Antioquia Mountain of the Central Cordillera, the city is classified as one of the regions most affected by landslides in Colombia. Large parts of the valley's mostly steep slopes are covered by old landslide deposits (Toro and Velasquez, 1984; GSM, 1999; Rendón, 1999, 2003) highly prone to the occurrence of different landslides types and flash floods.

Despite the unfavorable natural conditions, there was a 6fold increase in the population of Medellín between 1951 and 2005 exposing a large portion of its population to landslides. These landslides cause considerable damage to the environment and infrastructure, in addition to causing injury and loss of life. In the fourteen events recorded between 1880 and 2008, more than 750 people were killed and 7800 needed urgent assistance in the Medellín Valley (Table 1). The Iguaná watershed contributed by $38 \%$ to overall number of affected people and by $2 \%$ to the total death toll, while it covers only $13 \%$ of the Medellín city area.

Thus far, no attempt has been made to assess landslide susceptibility or hazard through systematic zonation despite the inherent instability and high levels of landslide activity in the area. Nonetheless, local authorities and central agencies (e.g. Office for the Coordination of Humanitarian Affairs)

Published by Copernicus Publications on behalf of the European Geosciences Union. 
Table 1. Major landslides within the Medellín Valley compiled according to Área Metropolitana (2007) and the local newspapers EL COLOMBIANO and EL TIEMPO. The highlighted localities indicate those landslides to have occurred within the Iguaná River Basin. The column "killed" refers to the number of persons confirmed as dead and/or persons missing and presumed dead. The column "affected" refers to the number of people requiring immediate assistance during the emergency period, i.e. displaced or evacuated people. Where a question mark occurs next to the type of mass movement, the process is uncertain.

\begin{tabular}{|c|c|c|c|c|c|c|}
\hline \multirow[t]{2}{*}{ Date } & \multirow[t]{2}{*}{ Locality } & \multirow{2}{*}{$\begin{array}{l}\text { Type of Mass } \\
\text { Movement }\end{array}$} & \multirow{2}{*}{$\begin{array}{l}\text { Geological } \\
\text { Materials }\end{array}$} & \multirow{2}{*}{$\begin{array}{l}\text { Slope } \\
\text { Conditions }\end{array}$} & \multicolumn{2}{|c|}{ Damage } \\
\hline & & & & & Casualties & Affected \\
\hline 23 May 1880 & La Iguaná & Debris flow & Debris and rock & $\begin{array}{l}\text { Low slope/ } \\
\text { alluvial fan }\end{array}$ & 9 & 2500 \\
\hline 12 Jul 1954 & Media Luna & Earth flow & $\begin{array}{l}\text { Residual soil/ } \\
\text { dunites }\end{array}$ & High slope & $>100$ & 67 \\
\hline 13 Apr 1972 & San Cristobal & Debris flow (?) & Heterogeneous & Moderate slope & 4 & - \\
\hline 25 Jun 1973 & La Manguala & Debris slide & Volcanic rocks & Scarp slope & 13 & 24 \\
\hline 29 Sep 1974 & Santo Domingo Savio & Earth flow & $\begin{array}{l}\text { Residual soil/ } \\
\text { dunites }\end{array}$ & Very high slope & $>70$ & 1500 \\
\hline 20 Oct 1980 & San Antonio & Debris flow & $\begin{array}{l}\text { Residual soil/ } \\
\text { granitic rocks }\end{array}$ & Very high slope & $>18$ & 250 \\
\hline 4 May 1982 & Santa Margarita & Debris flow (?) & Amphibolites & High slope & - & 200 \\
\hline 12 May 1982 & El Pesebre & Debris flow (?) & $\begin{array}{l}\text { Residual soil/ } \\
\text { granitic rocks }\end{array}$ & High slope & - & 250 \\
\hline 26 Sep 1985 & Popular 2 & Earth slide & $\begin{array}{l}\text { Residual soil/ } \\
\text { meta'phic rocks }\end{array}$ & High slope & 6 & 60 \\
\hline 27 Sep 1987 & Villatina & Complex slide-mud flow & $\begin{array}{l}\text { Residual soil/ } \\
\text { dunites }\end{array}$ & Very high slope & $>500$ & 3000 \\
\hline 30 Sep 1987 & Olaya Herrera & Earth slide (?) & Granitic rocks & Very high slope & - & 60 \\
\hline 3 Sep 1998 & Bello Horizonte & Debris flow (?) & $\begin{array}{l}\text { Residual soil/ } \\
\text { ophiolites }\end{array}$ & Very high slope & 2 & 13 \\
\hline 28 May 2007 & La Cruz & Earth slide & & & 7 & $>100$ \\
\hline 31 May 2008 & El Socorro & Earth flow & $\begin{array}{l}\text { Residual soil/ } \\
\text { granitic rocks }\end{array}$ & High slope & 27 & 120 \\
\hline 16 Nov 2008 & El Poblado & Slump-earth flow & $\begin{array}{l}\text { Residual soil/ } \\
\text { dunites }\end{array}$ & High slope & 12 & - \\
\hline
\end{tabular}

produce large amounts of information and digital data that are either directly or indirectly related to natural hazards. However, these bodies (also in other South American countries) often fail to maximize the use of available resources due to inappropriate data handling and the absence of relevant legislation. This problem is particularly acute when considered within the context of scarce economic funding, as greater investment into natural hazard mitigation should minimize future damages and losses. In this paper, we give an example of how pre-existing data can be used for landslide susceptibility and hazard assessment. Such assessments are extremely useful within the context of long-term land use planning with numerous examples in scientific literature (Corominas and Moya, 2008; van Westen et al., 2006; Chacón et al., 2006; Guzzetti et al., 1999). We also give some suggestions on how to improve existing landslide inventories with very little additional expenditure.

\section{The study area}

The Iguaná River watershed (Fig. 1) is located in the northwest part of the Medellín municipality covering an area of $51.22 \mathrm{~km}^{2}$. The Iguaná River rises at $2950 \mathrm{~m}$ a.s.l. and spills into the Medellín River at 1453 ma.s.l. Higher elevations and mainly the western and northern slopes of the watershed are characterized by steep inclination (over $25^{\circ}$ ) while the south slopes are less steep (often up to $12^{\circ}$ ). The majority of the watershed is covered by agricultural land with dispersed housing, whilst densely built-up areas tend to be concentrated along river banks and near its downstream confluence where the terrain is flatter.

The watershed is composed of Paleozoic metamorphic rocks such as gneisses, schist, and amphibolites. During the Cretaceous, ultrabasic rocks (e.g. dunites and gabbros) were 


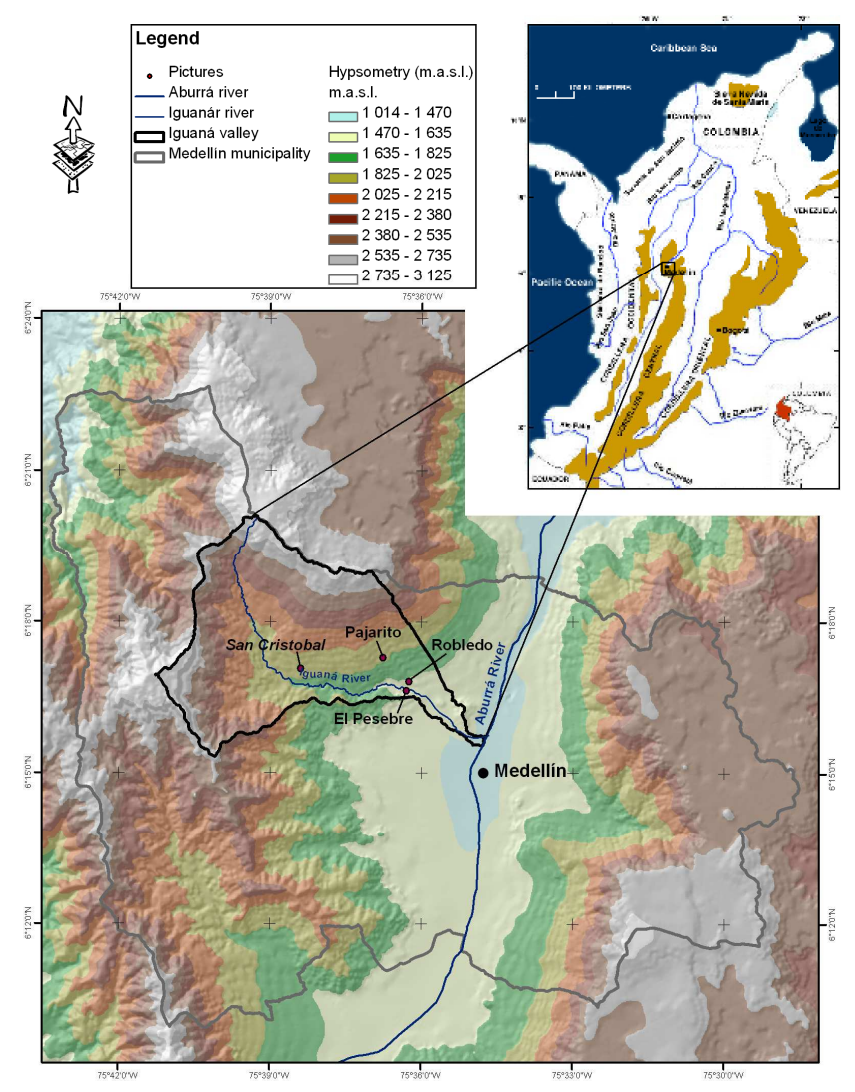

Fig. 1. Location of the Iguaná River Basin, Colombia.

thrust over these metamorphic rocks (Restrepo and Toussaint 1984). These ultrabasic rocks comprise a north-south trending ophiolite complex, which crosses the valley. Triassic and Cretaceous plutonic bodies, of acid to intermediate composition, frequently intrude into the metamorphic rocks. Above these lithologies, the watershed is frequently veneered by a weathered mantle depths from $10 \mathrm{~m}$ to $60 \mathrm{~m}$. This mantle is commonly observed in the highest parts of the watershed, and on northern and eastern slopes overlying amphibolites, schists, gabbros, gneisses and granitic rocks. On the less steep southern slopes, colluvial and debris or mud flow deposits dominate. These deposits contain highly variable compositions of sub-angular and angular pebbles, cobbles, boulders, or even blocks with heterogeneous silt-sandy matrix. In the valley, the thickness of the alluvial sediments varies from $15 \mathrm{~m}$ to $200 \mathrm{~m}$. These sediments contain well-sorted clays, silts, sands, and coarse gravels. In addition, anthropogenic materials such as trash and other debris are usually located close to the river on the lower slopes. It is estimated that these materials cover approximately $2 \%$ of the study area.

In general terms, the Andes are highly seismic. However, there have not been any registered earthquakes with a magnitude greater than $M=4$ in the vicinity of the study area between 1566 and 1999 (INGEOMINA). The majority of those earthquakes registered between 1993 and 2001 had a magni-

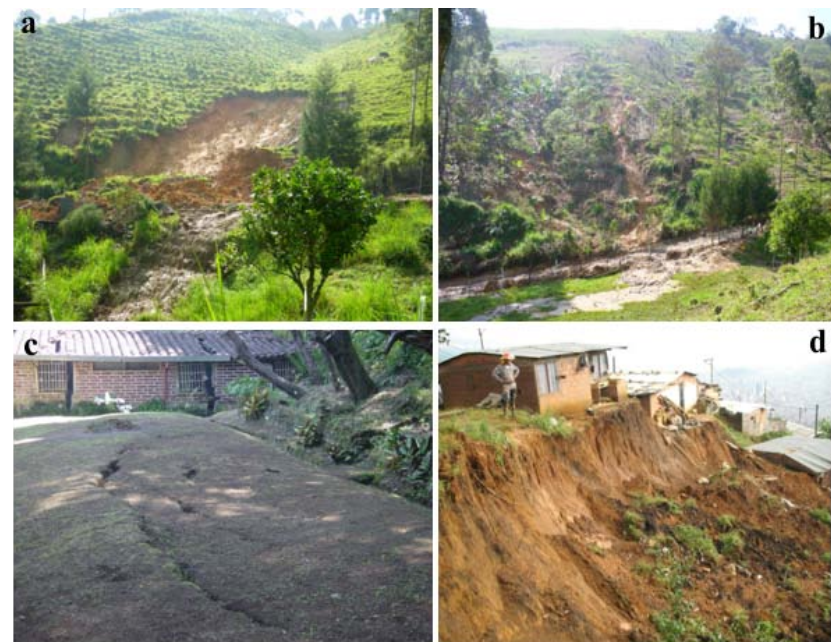

Fig. 2. Examples of the landslides recorded in the study area: (a) a rotational-translational slide in San Cristobal; (b) an earth flow in Pajarito; (c) a house affected by deep lateral spread in Robledo; and (d) a rotational slide in El Pesebre in November 2006, in which ten houses were destroyed and more than twenty five people affected (photos from SIMPAD).

tude of less than $M=3$ and an epicenter shallower than $30 \mathrm{~km}$ (INGEOMINA). A detailed catalogue of historical seismic events within the Medellín and Antioquia regions has been compiled for the Medellín Municipality, but it is yet to be published (Baquero et al., 2004). Nevertheless, it can be assumed that earthquakes have not played a major role in triggering landslides during the period for which the landslide inventory is available.

The study area is located within the tropical zone, and has a distinct bimodal rainfall distribution with maxima from April to May and October to November. Sporadic rainfall events of high-intensity and short-duration also occur during the rest of the year (Echeverri and Valencia, 2004). The average annual rainfall varies from $3000 \mathrm{~mm} / \mathrm{yr}$ in the northern and central parts of the valley to $1000 \mathrm{~mm} / \mathrm{yr}$ near the Medellín Valley (Moreno et al., 2006).

\section{Landslides inventories in the Iguaná watershed}

It is known that debris and earth flows constitute the two predominant types of landslide within the watershed, although rotational and deep seated translational slides have also been recorded along with occasional rock-falls and lateral spreads (Flórez, 2003; Aristizábal, 2004; Área Metropolitana, 2007). Examples of recorded landslides are shown in Fig. 2.

The first documented natural disaster caused by landslides in the watershed occurred on 23 April 1880. It was recorded that there were nine fatalities, with a further 2500 people affected (Hormanza, 1991). However, the scientific study of landslides only began in the early 1980's. A systematic 
landslide inventory was set up in 1992 when the Medellín Valley Metropolitan Area implemented a regional disaster database using the software DesInventar, developed by "La Red" Social Studies Network for Disaster Prevention in Latin America. This regional disaster database was compiled from data collected by Universidad EAFIT and SIMPAD (Municipal System of Disaster Prevention and Attention), as well as including results published by Hormanza (1991) and Saldarriaga (2003). In 2000, the local government created the "123: Emergency Phone Number Service". This forms the basis of a new database designed to store information relating to all reported natural and anthropogenic disasters within the city. It is managed by SIMPAD. Altogether 899 landslides are recorded in the both, "La Red" and SIMPAD databases covering the time span from 1988 to April 2008.

These databases contain information regarding the location referenced to the street address and date of a given landslide, as well as describing the human consequences (e.g. fatalities, injured, and affected persons). Unfortunately, they do not record information regarding the physical characteristics of the landslide e.g. landslide type and triggering factor. Useful data would include information regarding the antecedent conditions, the location of the uppermost scarp, the size of the surface area, or the volume of disturbed material. The absence of this information severely restricts the application of these databases to studies of landslide susceptibility and hazard assessment.

The design of the landslide inventories reflects the conclusions of Mora and Keipi (2006), that Latin world does not have culture of disaster prevention, but rather of immediate disaster response. The very detailed reports published by the Office for the Coordination of Humanitarian Affairs (www.colombiassh.org) are testament to this as the focus is on immediate response rather than the systematic collection of natural hazard data that would be of use in land use planning. Whilst such an approach clearly has certain advantages, detailed information about the exact nature of past landslide events would be of great help in areas of rapid population growth and increasing urbanization.

\section{Methods}

\subsection{Input data}

Information relating to individual landslides was extracted from the "La Red" and SIMPAD disaster databases. The first of these databases contains information on landslides between 1988 and 2002, whilst the second contains information on landslides between January 2004 and April 2008. The individual landslides had to be georeferenced using the street addresses of those houses that were damaged during the landslide event. From a total of 899 recorded landslides, 431 events were successfully located and used in the analysis. The location of these landslides is shown in Fig. 3a.
The topographic data comes from a digital terrain model (DTM) prepared by Montoya and Patiño (2001). The original contour map had contours every $2 \mathrm{~m}$ with a scale of 1:2000. This was converted to grid with a resolution of $5 \mathrm{~m}$. From this digital terrain model, a slope angle map has been constructed. The slope angles have been divided into five classes: (i) $0^{\circ}-$ $5^{\circ}$; (ii) $5^{\circ}-15^{\circ}$; (iii) $15^{\circ}-25^{\circ}$; (iv) $25^{\circ}-35^{\circ}$; and (v) $>35^{\circ}$ (Fig. 3b).

The superficial geology of the study area was compiled from the published literature (GSM, 1999; Rendón, 1999; Echeverri and Valencia, 2004; Aristizábal and Yokota, 2006; Área Metropolitana, 2007) using digital data layers prepared by Montoya and Patiño (2001) at scale 1:10 000. Numerous surface deposits are recognized, that are presented in Fig. 3c.

The land use was defined on the basis of vegetation cover density, agricultural practice, and crop type (Ojeda and Muñoz, 2001). Five categories could be distinguished on the map with original scale of 1:10000: (i) high vegetation; (ii) low vegetation; (iii) crop land; (iv) degraded soil; and (v) urban areas. These are presented in Fig. 3d.

\subsection{Landslide susceptibility and persistency analysis}

Two basic methods of landslide susceptibility assessment were used in the study area. The first is based uniquely on the landslide inventory, whilst the second assess susceptibility using weights based either on an expert understanding of the interactions that occur between the preparatory factors (e.g. slope angle, superficial geology, land use), and landslides or on a simple statistical description of these relationships. For this method, landslide densities were calculated for each variable of all preparatory factors.

The landslide inventory is considered to be the most elementary landslide susceptibility map (Glade and Crozier, 2005). It is assumed that the areas affected by known landslides represent the most susceptible areas. Since the landslides are represented only as points on the inventory map, we calculated their densities using "calculate density" option in the ArcView software. Thereafter, building densities were calculated. A comparison of these two maps was then used to identify those areas most susceptible to future landsliding and also to draw some basic conclusions about possible future damage locations.

The landslide susceptibility was evaluated by a direct method using expert knowledge about preparatory factors and landslide processes in the study area. The evaluated preparatory factors included slope, geological superficial formations and land use. Each variable of all factors was classified by expert judgment (including literature review) into 5 classes where 1 stays for the least susceptible variable and 5 for the variable most prone to landslide occurrence. Slope classes have been divided using simple assumption, steeper the slope more landslides prone it is. Land use was evaluated regarding its expected role in water infiltration process. Thus the least favorable environment for landslide occurrence was 

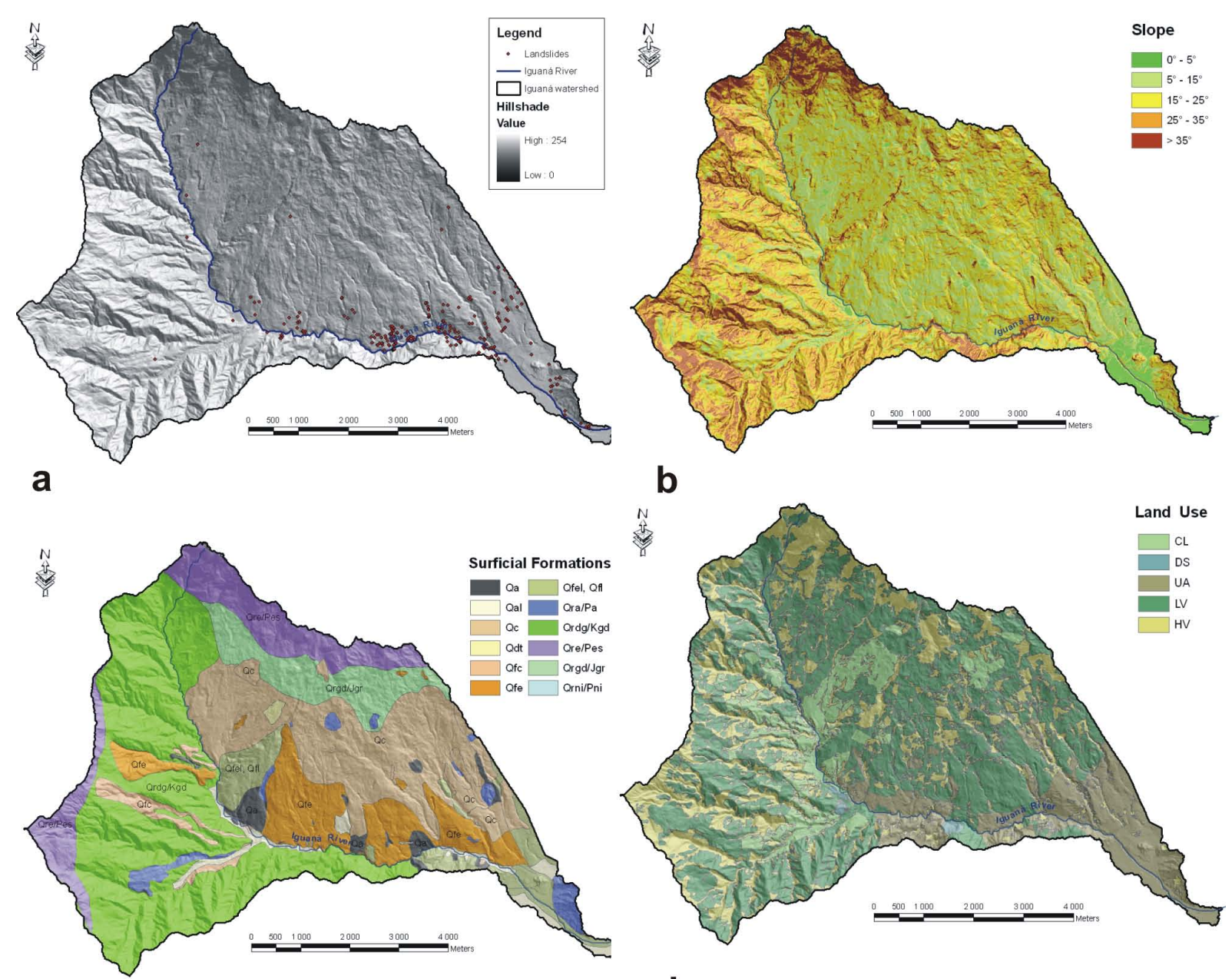

b

C

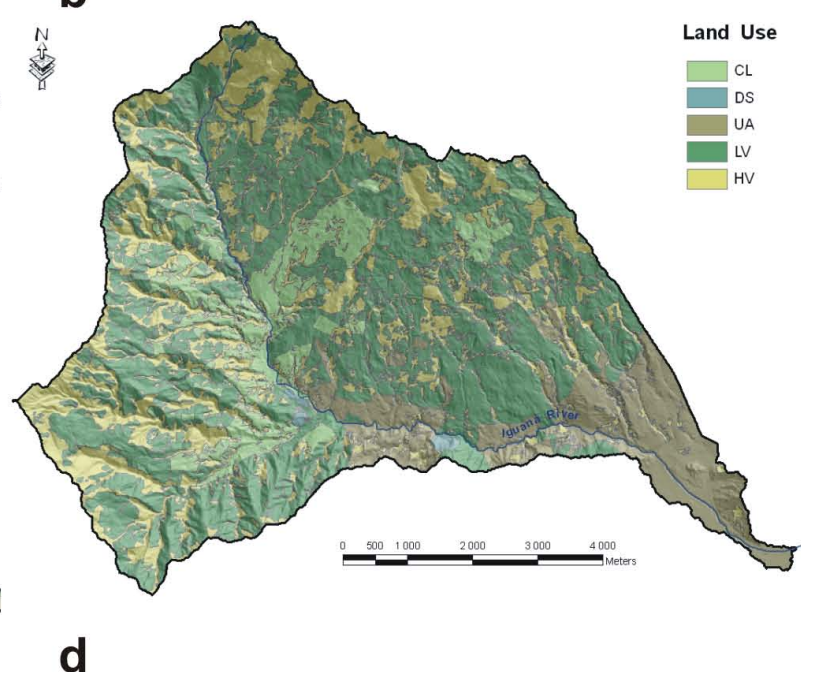

Fig. 3. Input data layers: (a) landslide map; (b) slope map; (c) superficial geology; (d) land use.

For c: Qa - anthropogenic deposits; Qal - alluvial deposits; Qc - colluvial deposits; Qdt - detritus deposits; Qfc - consolidate deposits; Qfe - debris flow deposits; Qfel - mud/debris flow deposits; Qra/Pa - residual soil/amphibolites; Qrdg/Kgd - residual soil/Altavista's stock; Qre/Pes - residual soil/schists; Qrgd/Jgr - residual soil/Romeral gabbro; Qrni/Pni - residual soil/Iguaná gneiss.

For d: CL - cropped land; DS - degraded land, UA - urban areas; LV - low vegetation; HV - high vegetation (after Planeación Municipal, 1999).

assumed areas covered by trees and forest (e.g. high vegetation land use class), whereas the most favorable conditions were attributed to the degraded soil which lacks vegetation cover. Surficial deposits were classified according their observed or described susceptibility to landslide occurrence. Then the adjusted general linear model (Guzzetti et al., 1999; Dai and Lee, 2002) was used to sum up susceptibility weights assigned to each variable of all predictor factors (Eq. 1):

$\mathrm{LS}=B_{1} E_{1}+B_{2} E_{2}+\ldots+B_{n} E_{n}$

Where LS is the landslides susceptibility predictor value of a given pixel, $E$ 's are expert predictor values of each variables of each preparatory factor (Table 2 ), e.g. slope angle classes $0^{\circ}-12^{\circ}, 12^{\circ}-25^{\circ}$ and $B$ 's are coefficients weighting importance of different preparatory factors among the others. We assume that the geological superficial formations $(B=3)$ are the most important factor followed by the slope $\operatorname{dip}(B=2)$ and the land-use $(B=1)$ is the least important.

Secondly, the equation for assessing the landslide susceptibility using weights that were calculated as landslide densities (LD's in Eq. 2) for each variable of preparatory factors (Table 3 ) is the following:

$\mathrm{LS}=B_{1} \mathrm{LD}_{1}+B_{2} \mathrm{LD}_{2}+\ldots+B_{n} \mathrm{LD}_{n}$

The resulting landslide susceptibility classes are defined as follows for the potential end-user: (i) very low: no landslides should initiate in this area, only limited number of accumulations of landslides with long run-out may reach this zone; (ii) low: initiation of landslides is rare but can not be entirely excluded due to local variability of preparatory factors or under extreme triggering conditions (e.g. extremely heavy precipitation); (iii) moderate: initiation of landslides is possible; 
(iv) high: areas with conditions very favorable for landslide occurrence; (v) very high: majority of these slopes will fail in near future. Implication of the susceptibility classes for land use planning purposes was also defined in this study.

Assessing the spatial distribution of landslides recorded during subsequent years (2004-2008) enabled calculation of the landslide persistence as the portion of new landslides occurring very close to the locations of landslides from the previous years (Cardinali et al., 1999; Rybáŕ, 1999; Malamud et al., 2004). For the purposes of this study, "very close to" is defined as within a $50 \mathrm{~m}$ circular buffer zone.

\subsection{Damage analysis}

The information from both databases was merged to create two classes. First, affected houses indicating those buildings that had to be temporarily evacuated or were damaged but which could be re-inhabited following reconstruction. Second, destroyed houses indicating those buildings that were irreparably damaged during the event and had to be abandoned. A statistical overview of these data for the available time periods (1984-2002 and 2004-2008) was prepared. Injured persons are those who needed medical treatment due to injuries suffered during a landslide event. Affected persons needed immediate assistance during and shortly after the damaging event (e.g. temporarily evacuated people) and disappeared persons are those claimed missing due to the landslide event.

\subsection{Temporal occurrence of landslides and landslide hazard}

The temporal distribution of recorded landslides (1984-2002 and 2004-2008) were analyzed on a month-by-month basis and compared to the record of average monthly precipitation. In addition, the landslide record was compared with respect to El Niño, "normal", and La Niña precipitation years. The climatic classification of each year was taken from the Western Regional Climate Center (WRCC ${ }^{1}$ ) and the Center for Oceanic-Atmospheric Prediction Studies $\left(\mathrm{COAPS}^{2}\right)$. The average annual precipitation and monthly temperature minima and maxima were taken from the World Meteorological Organization $\left(\mathrm{WMO}^{3}\right)$. Information about evaporation for Medellín City was taken from the Institute of Hydrologic, Meteorological and Environment Studies (IDEAM ${ }^{4}$ ). Landslide damage was defined as the sum of affected and destroyed houses.

\footnotetext{
${ }^{1}$ http://www.wrcc.dri.edu/enso/ensodef.html, last access: 27 November 2009

2 http://www.coaps.fsu.edu/jma.shtml,

last access: 27 November 2009

${ }^{3} \mathrm{http}: / /$ worldweather.wmo.int/057/c00159.htm, last access: 27 November 2009

${ }^{4}$ Instituto de Hidrologia, Meteorologia y estudios ambientales, http://www.ideam.gov.co/, last access: 9 December 2009
}

Even though not complete, the available landslide databases were used to calculate basic characteristics of landslide frequency and occurrence probabilities to assess the landslide hazard within the study area using the definitions in Fell et al. (2008) and Corominas and Moya (2008). The average annual landslide frequency per square kilometer and landslide return period were used to define landslide hazard. Following the ERM-Hong Kong, Ltd. (1998) suggestions, the average annual probabilities of a house being damaged and of a person being killed by a landslide were also calculated.

\section{Results}

\subsection{Landslide susceptibility and persistency analysis}

The landslide susceptibility map derived from Eq. (1) is presented in Fig. 4. Landslide densities used for the weighted landslide susceptibility model are shown for each preparatory factor variable in the Table 3 . The percentages given for the following classes represent the complete range of landslide susceptibility values derived from Eq. (2), i.e. the highest landslide susceptibility value corresponds to $100 \%$. The five classes are: (i) $0-25 \%=$ very low susceptibility; (ii) $25-45 \%=$ low susceptibility; (iii) $45-55 \%=$ moderate susceptibility; (iv) $55-75 \%=$ high susceptibility; and (v) 75$100 \%=$ very high susceptibility. The susceptibility map showing these classes is on Fig. 4. It should be noted that for land use, the coefficient $B$ was lowered (to value of 0.5 ) to further reduce the impact of this environmental factor. This factor is considered to be overestimated by the density calculation since most of the reported landslides are located within urban areas, whilst it can be assumed that at least some of the landslides that occurred in other areas (e.g. degraded land or high vegetation) went unreported. Furthermore, urban areas are unlikely to be associated with the most favorable conditions for landslide initiation as the majority of housing is constructed on relatively flat terrain.

A validation of both landslide susceptibility maps with the available landslide data used in the preparation of the weighted map shows both maps to be satisfactory, although better results are achieved with the weighted map (Table 4). More then $87 \%$ of the recorded landslides were assigned to areas of high or very high landslide susceptibility. Furthermore, only $0.2 \%$ of the recorded landslides were assigned to areas of very low landslide susceptibility. Similar results were achieved when validating the susceptibility maps only with the landslides recorded during the 2004-2008 period. It is because of more than $71 \%$ of all available landslides were recorded during this time span. Of particular significance is that both susceptibility maps demonstrate that more than $50 \%$ (51.1\% on the expert-based susceptibility map and $82.4 \%$ on the weighted susceptibility map) of the buildings within the Iguaná River Basin are located in areas of high or very high landslide susceptibility. 
Table 2. Expert classification of predictor factors and their variables ( $E$ 's in Eq. (1), $1=$ least susceptible; $5=$ most susceptible).

\begin{tabular}{|c|c|c|c|}
\hline $\begin{array}{l}\text { Classification of } \\
\text { Predicted Variables } \\
(E)\end{array}$ & Surficial Deposits & Land Use & Slope \\
\hline 1 & $\begin{array}{l}\text { Alluvial deposits } \\
\text { Consolidate deposits } \\
\text { Residual soil of the Romeral gabbro } \\
\text { Residual soil of the Iguaná gneiss }\end{array}$ & High vegetation & $0^{\circ}-5^{\circ}$ \\
\hline 2 & $\begin{array}{l}\text { Residual soil of amphibolites } \\
\text { Residual soil of schists }\end{array}$ & Urban areas & $5^{\circ}-15^{\circ}$ \\
\hline 3 & $\begin{array}{l}\text { Anthropogenic deposits } \\
\text { Colluvial deposits }\end{array}$ & Low vegetation & $15^{\circ}-25^{\circ}$ \\
\hline 4 & $\begin{array}{l}\text { Talus deposits } \\
\text { Residual soil/Altavista stock }\end{array}$ & Cropped land & $25^{\circ}-35^{\circ}$ \\
\hline 5 & $\begin{array}{l}\text { Debris flow } \\
\text { Mud/debris flow deposits }\end{array}$ & Degraded soil & $>35^{\circ}$ \\
\hline
\end{tabular}

Table 3. Landslide densities used for the weighted susceptibility map.

\begin{tabular}{lccccc}
\hline Surficial formations & $\begin{array}{c}\text { Landslide } \\
\text { densities } \\
(\%)\end{array}$ & Land use & $\begin{array}{c}\text { Landslide } \\
\text { densities } \\
(\%)\end{array}$ & $\begin{array}{c}\text { Slope } \\
\text { Landslide } \\
\text { densities } \\
(\%)\end{array}$ \\
\hline $\begin{array}{l}\text { Talus deposits } \\
\text { Residual soil/Schists }\end{array}$ & 0 & & & & \\
Residual soil/Romeral's Gabbros & 0 & Degradated soil & 0.23 & $>35^{\circ}$ & 0.93 \\
Residual soil/Iguaná's Gneiss & 0.70 & & & & \\
Consolidate deposits & 0.46 & & & & \\
Mud/debris flow deposits & 3.02 & Cropped land & 0.46 & $0^{\circ}-5^{\circ}$ & 7.19 \\
Residual soil/Amphibolites & 9.98 & High vegetation & 2.09 & $25^{\circ}-35^{\circ}$ & 22.51 \\
Anthropogenic deposits & 10.67 & & & & \\
Alluvial deposits & 14.15 & Low vegetation & 7.43 & $15^{\circ}-25^{\circ}$ & 32.94 \\
Colluvial deposits & 13.46 & & & & \\
Residual soil/Altavista's Stock & 15.08 & Urban areas & 89.79 & $5^{\circ}-15^{\circ}$ & 36.43 \\
Debris flow & 32.48 & & & & \\
Mud-flow deposits & & & & & \\
\hline
\end{tabular}

Landslide densities calculated from the landslide inventories are shown on Fig. 5. The areas with high landslide and building densities are displayed in red, whereas the high landslide and low building densities are shown in orange. Whilst both areas are highly susceptible to the effects of landslides, the difference in building density is critical to future land use planning. In red areas, the highest future damages may be expected due to repeating landslide occurrence on heavily build up regions. The highly developed nature of these localities means that future land use planning should focus upon effective landslide mitigation and disaster response. In orange areas, the less developed nature of these localities means that future expected damage resulting from high landslide densities can be limited by restricting building development, or applying strict and effective building codes on future housing development. The reliability of this map is clearly limited by the data recorded in the available inventories which do not include all landslides occurred in the Iguaná River Basin.

Landslide persistency calculated for the study area is in average $35 \%$, but the year 2008 should be excluded from the calculation since it does not include whole year (the record ends in the April). After the adjustment, the average persistence drops to $28 \%$. From this, it can be inferred that approximately one-third of all landslides to occur next year will be located within $50 \mathrm{~m}$ of already recorded landslide. It is important to keep in mind, that this figure may vary enormously. 

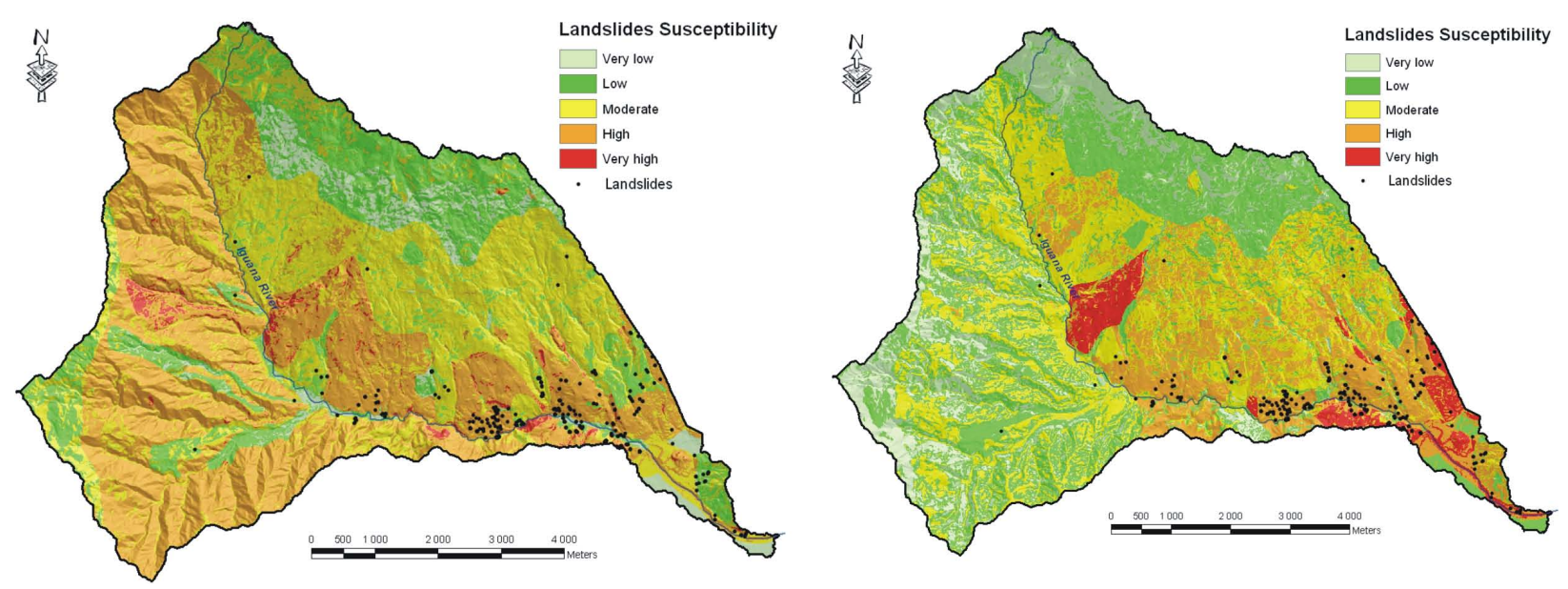

Fig. 4. Expert based (left) and weighted (right) landslides susceptibility map.

Table 4. Comparison of the expert-based and weighted landslide susceptibility maps of the Iguaná River Basin using the all available landslide records $\left(^{*}\right)$ and landslides recorded between 2004 and $2008\left(^{* *}\right)$.

\begin{tabular}{|c|c|c|c|c|c|c|c|c|}
\hline \multirow{2}{*}{$\begin{array}{l}\text { Susceptibility } \\
\text { class }\end{array}$} & \multicolumn{4}{|c|}{ Expert susceptibility map } & \multicolumn{4}{|c|}{ Weighted susceptibility map } \\
\hline & $\%$ of study area & $\%$ of 1 & adslides & $\%$ of buildings & $\%$ of study area & $\%$ of 1 & Idslides & $\%$ of buildings \\
\hline Very low & 4.9 & $9.5^{*}$ & $9.0^{* *}$ & 4.1 & 15.1 & $0.2^{*}$ & $0.3^{* *}$ & 0.2 \\
\hline Low & 17.9 & $11.8^{*}$ & $10.4^{* *}$ & 18.9 & 31.7 & $8.3^{*}$ & $8.4^{* *}$ & 6.2 \\
\hline Moderate & 34.8 & $22.7^{*}$ & $23.8^{* *}$ & 25.9 & 31.8 & $3.9^{*}$ & $3.6^{* *}$ & 11.1 \\
\hline High & 40.9 & $55.4^{*}$ & $56.3^{* *}$ & 50.7 & 17.2 & $74.2^{*}$ & $58.3^{* *}$ & 68.5 \\
\hline Very high & 1.5 & $0.5^{*}$ & $0.6^{* *}$ & 0.4 & 4.2 & $13.2^{*}$ & $29.4^{* *}$ & 13.9 \\
\hline
\end{tabular}

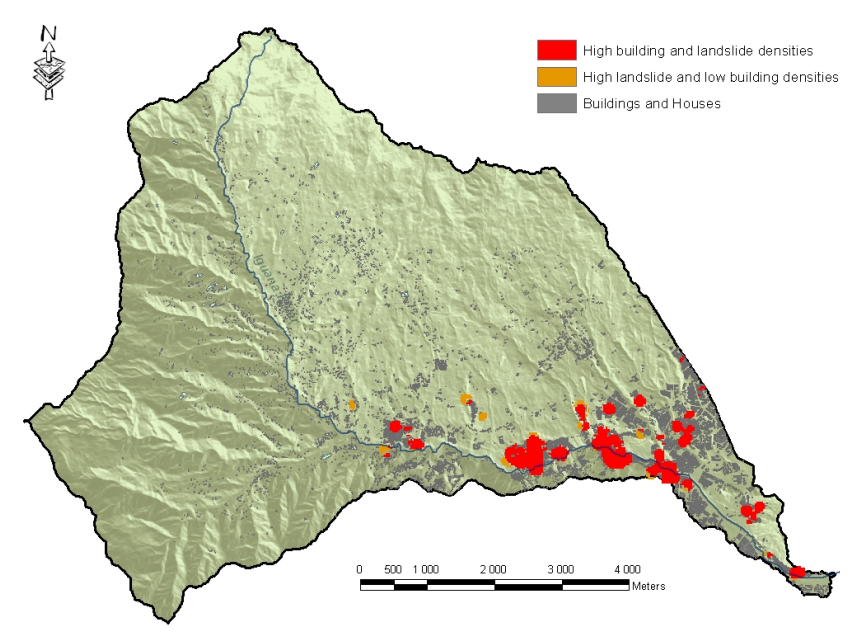

Fig. 5. Map showing areas with high landslide and building densities (red), and high landslide and low building densities (orange).

When the landslide density per unit area is divided by number of years covered by landslide records (20 years), basic hazard map with two hazard classes (high frequency orange and red colors, low frequency - the rest of the study area) is defined.
Table 5. Damages caused by all recorded landslides in the Iguaná River Basin since 1984.

\begin{tabular}{lc}
\hline Damage & Count \\
\hline Dead persons & 4 \\
Injured persons & 7 \\
Disappeared persons & - \\
Affected persons & 141 \\
Temporal evacuated houses & 159 \\
Affected houses & 97 \\
Destroyed houses & 37 \\
Permanently evacuated houses & 115 \\
\hline
\end{tabular}

\subsection{Damage analysis}

Since 1984, an average of 40.7 landsides has occurred every year in the Iguaná River Basin. Total of 141 people have been affected (Table 5). This works outs at an average of 0.16 persons affected per event. The number of people affected is quite low, when compared to those figures reported in the National Catalogue of Mass Movements (INGEOMINAS, 2002) which states that an average of 3 to 4 persons are affected per event. 


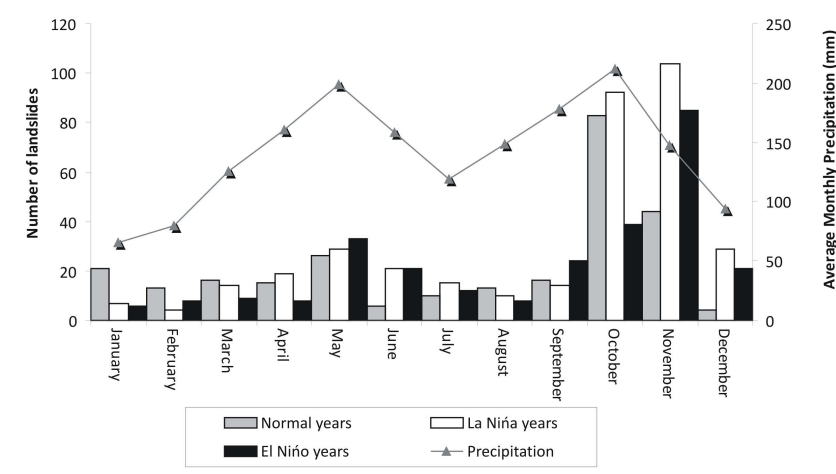

Fig. 6. Graph showing the correlation between the total number of landslides per month, classified according to the average monthly precipitation and weather pattern. Precipitation information is based on the monthly average calculated over a 30-year period (1971-2000) $\left(\mathrm{WMO}^{3}\right)$.

\subsection{Temporal occurrence of landslides and landslide damage}

The average monthly precipitation is strongly bimodal. However, this distribution is only partly reflected by the landslide frequencies. Two more-or-less equal peaks in the precipitation occur during May and October (Fig. 6). In contrast, $50 \%$ of all registered landslides occur in the later of these rainy seasons whereas only $19 \%$ of all registered landslides occur in the earlier of these rainy seasons. When excluding three months with the highest landslide activity (May, October, November), average of 40 landslides per month occurred during the 22 years time period. The average annual landslide occurrence frequency for May is 4, for October and November it is 10 and 11 respectfully and 1.5 for the other months.

The landslide distribution during La Niña and El Niño years has several distinct features when compared to "normal" years. During La Niña and El Niño years, the occurrence of landslides remains high in June, while during the "normal" years it sharply drops down to the $77 \%$ of the May occurrences Furthermore, there is also a distinct shift in the timing of peak landslide occurrence during the later rainy season. This occurs in October during "normal" years, but in November during La Niña and El Niño years. However, there are also differences between La Niña and El Niño years. The main difference stems from the gradual initiation of the later maximum during El Niño years. For example, during an El Niño year the number of landslides starts to increase in September (when the number of landslides increases by $67 \%$ from August) and reaches its maximum in November (when the number of landslides increases by $55 \%$ from October). During a La Niña year, the number of landslides increases dramatically in October (when the number of landslides increases by $85 \%$ from September). In a "normal" year, the number of landslides in November drops appreciably (when

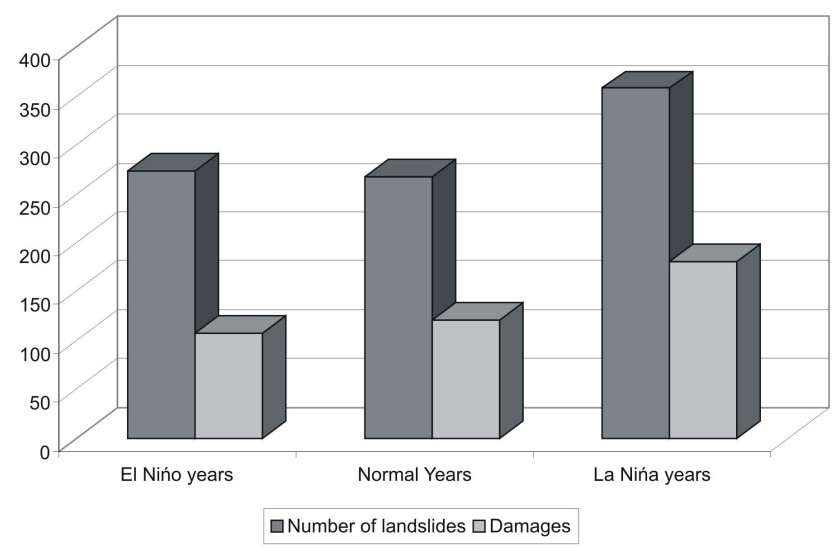

Fig. 7. The annual distribution of landslides and landslide damage (affected and destroyed houses) summarized for El Niño, "normal", and La Niña years.

the number of landslides decreases by $47 \%$ from October). In contrast, the number of landslides reaches its maximum during November in both La Niña and El Niño years. The total number of recorded landslides is greatest in La Niña years.

Dominance of landslide occurrence during La Niña years confirms comparison of the total number of landslides and damaged houses during El Niño/La Niña and "normal" years. The greater number of landslides during La Niña years is also confirmed by a comparison of the total amount of damage to occur during La Niña, "normal", and El Niño years (Fig. 7). The values derived for "normal" and El Niño years are similar, both in terms of the number of landslides and the amount of damage. During a La Niña year, however, the total number of landslides is $38 \%$ greater and the total amount of damage is $65 \%$ greater. Also average damage per landslide is highest during the La Niña years (0.5) and it is lowest during El Niño years (0.39), while "normal" years are in between both previous values $(0.45)$.

\subsection{Landslide hazard}

To only use the available "La Red" and SIMPAD disaster databases as the basis for a reliable landslide hazard assessment is problematic because of the incomplete nature of the landslide inventories which exclude landslides that did not cause damage. The completeness of inventories is basic requirement for the hazard assessment (Corominas and Moya, 2008). The average annual landslide frequency for the 5 year period (2004-2008) is 1.3 per $\mathrm{km}^{2}$ per year resulting in a 0.015 year landslide return period. This suggests that the landslide hazard of the Iguaná River Basin is either high (Fell et al., 2008) or very high (Corominas and Moya, 2008). As the average number of houses damaged per registered landslide is known to be 0.3 , it is possible to calculate that the average annual landslide frequency of events able to cause 
damage is 0.43 landslides per $\mathrm{km}^{2}$ per year. There are a total of 27352 houses in the watershed, which gives the average annual probability of a house being damaged by a landslide as $1.6 \times 10^{-5}$. Similarly, the average annual probability of a person being killed by a landslide (based on the 22 year record) is $1.6 \times 10^{-5}$. These figures are deemed to be acceptable, according to the criteria described by ERM-Hong Kong, Ltd. (1998). Missing information about landslide type and magnitude and possible gaps in the landslide inventory in areas where no settlement is present makes it impossible to perform landslide hazard zoning of the watershed. Thus the calculated landslide probability occurrence is attributed to the whole studied watershed showing that the landslide occurrence is high enough to justify further effort in landslide inventory improvement.

\section{Discussion}

The presented results demonstrate that even an incomplete landslide dataset can be used to determine landslide susceptibility with a reasonable degree of reliability. These results are useful as a guide for future land use planning. It is suggested that the most detailed scale at which the weighted susceptibility map should be used is 1:50 000 due to any possible errors introduced during the georeferencing procedure. The most detailed scale at which the specialist-based susceptibility map can be used is defined by the scale of the input data. In this study, the input data is no smaller than 1:10000 and therefore this is considered to be an appropriate scale.

Another requirement for the map's applicability is the definition of the susceptibility classes with respect to land use planning. The very low and low susceptibility classes are suitable for future development, although other potential natural hazards such as flooding or seismicity should be considered before any such decision is made. The moderate and high susceptibility classes may be suitable for future development, although local stability assessments should be undertaken by experienced personnel before any such decision is made (Fell et al., 2008); placing critical infrastructure, such as hospitals or schools, into these areas is not recommended. The very high susceptibility class is not suitable for future development, and the possibility of relocating existing settlements should be considered along with preventative landslide mitigation measures that are able to secure existing buildings and infrastructure. It is also important to bear in mind that those regions up-slope from high and very high susceptibility classes may pose a serious threat as possible landslide source areas which were recorded in the databases in form of points placed within their accumulation and transport parts, but actually could initiated up slope from these locations.

The information recorded in the databases has not yet been standardized. For example, the landslides are located by the closest street address within the city. Two problems are asso- ciated with this system. First, there is no fixed rule governing how an address is written and each city has its own template. Second, in rural areas a description may be used instead of a street address. Consequently, the geocoding process undertaken in ArcGIS is liable to certain errors. In fact, it was not possible to match $52.06 \%$ of the total landslide events because the address recorded in the database could not be matched to a point on the ground. To optimize the geocoding processes it is necessary to establish conventions regarding the recording of landslide localities.

The specific issues regarding quality and reliability of the prepared susceptibility maps are discussed in the following paragraphs. The weighted susceptibility map is associated with certain drawbacks. These stem from the representation of landslides as points. A point is placed within the landslide area without explanation if it is located within scarp, transport or accumulation parts of the landslide. Definition of the relationship between preparatory factors and landslides based only on points provides considerably smaller amount of information compared to landslide area defined as a polygon. These drawbacks explain the unusual relationship between landslide densities and slope angle. The highest landslide density is in the $0^{\circ}-5^{\circ}$ interval decreasing with increasing slope with minimum on the slopes with dip $>35^{\circ}$. It sharply contrasts with slope dip landslide relationships described in literature (Castellanos and van Westen, 2001; Dai and Lee, 2002; Nadim et al., 2006). This bias behavior of the studied landslides can be explained by the fact that the points representing the landslides were placed near houses generally constructed on flat areas which could develop below landslide scarps or within their transport or accumulation parts. Consequently, the environmental factors responsible for the initiation of the landslide remain largely unconstrained (Guinau et al., 2005). There may be a similarly biased relationship between landslides and superficial geology. For example, fewer landslides would be expected to be reported to occur on alluvial deposits; depending on that which occurs up-slope of the alluvial deposit, some of those may be better attributed to colluvial, anthropogenic, or debris and debris/mud flow deposits (Fig. 3a). This bias is due to the fact that landslide locations reported to databases referred to the toe areas instead to the scarp areas. Also the highest landslide density on urban areas is caused by the way how the landslide data are collected and does not reflect more favorable conditions for landslide occurrence. These errors are not presented within the expert-based susceptibility map.

Despite of the differences in defining relationship between landslides and their preparatory factors for expert and weighted susceptibility models, they show in general similar picture about relative landslide susceptibility of the area. Lowest landslide susceptibility is within the highest parts of the watershed bellow both north and east ridges. Moderate susceptibility class is typical for the middle parts of the slopes on the left side of the Iguaná River, whereas the high and very high susceptibility classes occur on lower parts of 
the same slopes. Largest differences in the susceptibility are found on the mostly east facing slopes dissected by rightbank tributaries of the Iguaná River, where the expert susceptibility map identified high and also very high susceptibility classes. The weighted model is less conservative and displays very low to moderate susceptibility classes there. But even in this case we can observe that the weighted susceptibility map placed several pixels with high susceptibility into the same sub-basin where the expert model suggest very high susceptibility and the two other tributary valleys in the southern part of this region display on both maps low or very low susceptibility. We consider this general agreement of the two maps as a validation of our results showing that the maps were able to correctly distinguish the most susceptible parts of the study region regardless different approaches used for their preparation and drawbacks of the landslide input data.

It has already been noted that there is a much higher number of landslides during the second rainy season (SeptemberNovember) than compared to the first (April-June). Moreno et al. (2006) noted that the soil water becomes highly saturated during the first rainy season and that this situation persists until the second rainy season begins. The higher number of landslides recorded during the second rainy season is a function of the antecedent soil water conditions. The accumulative differences between the average monthly precipitation and the total evaporation (IDEAM ${ }^{4}$ ) show that a much higher amount of water is available for the later rainy season (Fig. 8). The relative water deficit observed at the beginning of the year is caused by the comparatively high evaporation and low precipitation in the period from January to March.

An analysis of the temporal distribution of landslides revealed a prolonged maximum between October and November when the area is subjected to either La Niña or El Niño weather patterns. Moreover, considerably greater landslide activity occurs within La Niña years. This is attributed to the strong positive precipitation anomalies described by Poveda at al. (2005), as the average daily total rainfall is $5.7-40 \%$ greater than it is during "normal" years and $48 \%$ greater than it is during El Niño years. El Niño years are characterized by negative precipitation anomalies, especially between September and February. This negatively affects the later rainy season, during which the majority of landslides usually occur. Taken together, these data suggest that landslides are triggered as a result of shorter-term precipitation patterns rather than the accumulative affect of precipitation over longer periods. This assertion conforms to the suggestion of Moreno et al. (2006), who concluded that 15 days of accumulative precipitation are important for triggering landslides within the study area. The realization that increased landslide activity and associated damage occurs during $\mathrm{La}$ Niña years (65\% higher than in "normal" or El Niño years) may be particularly useful for local authorities and civil defenses, as these institutions are now able to plan (and budget for) more effective landslide mitigation and relief action during La Niña years.

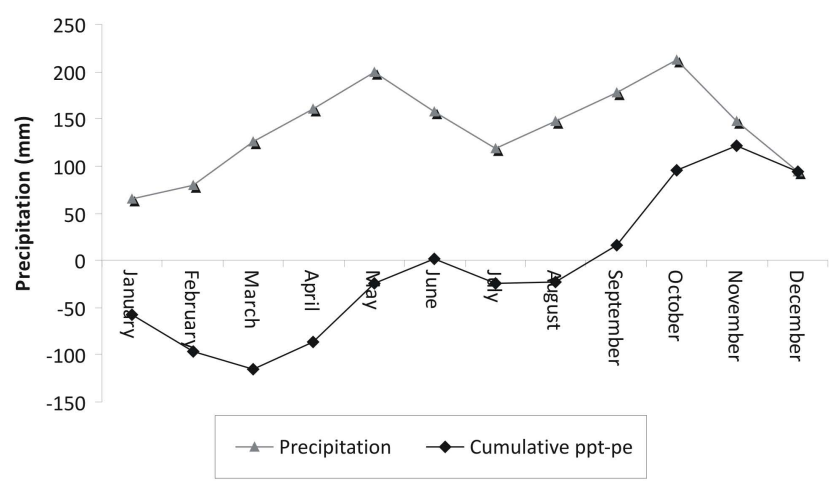

Fig. 8. The average monthly precipitation calculated over a 30 year period (1971-2000) (WMO) and the accumulative difference between the monthly average precipitation and evaporation, as provided by IDEMA.

Suggestions on easy to implement improvements of the available landslide databases are summarized in this paragraph. The major step toward more reliable susceptibility and hazard zoning of the area under study would be to include maps showing limits of each landslide. Such information is partly available in detailed geological reports (L. J. Mejia, personal communication, 2009) along with information about landslides outside build up areas, which can be obtained from aerial pictures or satellite images (Cardinali et al., 1999). Their regular updating should be also insured. Useful guidelines on what information should be stored within the landslide inventories can be found elsewhere (e.g. Malamud et al., 2004; Fell et al., 2008). We assume that institutional conditions for improving the existing database are good in the Medellín municipality, nevertheless clear operational framework is necessary to ensure applicability of the best available data for decision making procedures.

We also wanted to contribute to the discussion of using the susceptibility and hazard assessment during the land development process, which seems to be partly neglected in the Latin world so far. Nevertheless, it is worth to note that even in countries with well established development regulations considering natural disasters as limiting factor gaps between scientific knowledge, legal rules and decisions taken by the responsible authorities cause large damages.

\section{Conclusions}

This study has used existing disaster databases (inventories) in order to examine the spatial and temporal variability of landsliding within the Iguaná River Basin near Medellín City, Colombia. The spatial variability of landsliding was examined using "expert-based" and "weighted" landslide susceptibility models. The constructed landslide susceptibility maps demonstrate consistent results irrespective of the used 
method. These show that at least $55.9 \%$ of the watershed is highly or very highly susceptible to landsliding. Each susceptibility class has clearly defined meaning for the land use planning purposes. Furthermore, a landslide density map and analyses of landslide persistency has enabled specific recommendations about the future land use planning of the area. Thus the main constrains of applying such result within the study area is not missing knowledge, technical skills or scarce economic resources but possible lack of legal or operational rules at the local scale.

The temporal distribution of landsliding was analyzed and compared with climatic data. The area has a distinct bimodal rainfall distribution, and it is clear that landsliding is particularly frequent during the later rainy season between October and November. Moreover, landslides are more common during La Niña years. This information is of value to local authorities when they need to prepare post-disaster action plans. It is recommended that the existing landslide inventories are improved so as to be of greater use in the future land use planning of the area. Much of the requisite data is already being collected by different agencies (e.g. geological reports about serious landslides). The integration of these data would substantially improve information on landsliding for a minimal cost. The construction of landslide susceptibility maps based on widely available data represents a significant step towards landslide mitigation in the area and also may be used in different locations with similar landslide inventory drawbacks. Using susceptibility and hazard assessment presented in the article during the developmental process should reduce the need for disaster response at a later stage.

Acknowledgements. Financial support for the project was provided by the Czech Science Foundation (Grant No. 205/09/P383). We would particularly like to thank Luz Jeanette Mejia from SIMPAD and Beatriz Susana Acosta from EAFIT for supplying the information used in this article.

Edited by: T. Glade

Reviewed by: two anonymous referees

\section{References}

Alexander, E. D.: Urban landslides, Progress in Physical Geography, 13, 157-191, 1989.

Alcántara-Ayala, I.: Geomorphology, natural hazards, vulnerability and prevention of natural disasters in developing countries, Geomorphology, 47, 107-124, 2002.

Área Metropolitana: Diseño del sistema metropolitano para la prevención, atención y recuperación de desastres del Valle de Medellín, Tomo 1, Contrato No. 517 de 2005, available at: http://www.metropol.gov.co (last access: 15 June 2008), 2007 (in Spanish).

Aristizábal, E.: Geomorphological evolution of the Medellín Valley, northern Colombian Andes, and implications for landslide occurrence, M.Sc. thesis, Shimane University, Colombia, 156 pp., 2004.
Aristizábal, E. and Yokota, S.: Geomorfología aplicada a la ocurrencia de deslizamientos en el Valle de Medellín, DYNA, 149, 5-16, 2006 (in Spanish).

Baquero, A. E., Capera, A. A. G., Hurtado, E. J. S.: State-of-the-art of the historical seismology in Colombia, Ann. Geophys.-Italy, 47, 437-439, 2004.

Castellanos, E. A. and van Westen, C. J.: Geomorphology and geology of San Antoni del Sur, Guantanamo, Cuba: its contribution in producing landslides, in: Proceedings of GEOMIN 2001, Geologia y Mineria: memorias trabajos y resúmenes, La Habana, Cuba, 19-23 March 2001, 84-93, 2001.

Cardinali, M., Ardizzone, F., Galli, M., Guzzetti, F., and Reichenbach, P.: Landslides triggered by rapid snow melting: the December 1996-January 1997 event in central Italy, in: Mediterranean Storms, Proceedings of the EGS Conference, Maratea, Italy, October 1999, 439-448, 1999.

Chacón, J., Irigaray, C., Fernández, T., and El Hamdouni, R.: Engineering geology maps: landslides and geographical information systems, B. Eng. Geol. Environ., 65, 341-411, 2006.

Corominas, J. and Moya, J.: A review of assessing landslide frequency for hazard zoning purposes, Eng. Geol., 102, 193-213, 2008.

Dai, F. C. and Lee, C. F.: Landslide characteristics and slope instability modeling using GIS, Lantau Island, Hong Kong, Geomorphology, 42, 213-228, 2002.

Echeverri, O. and Valencia, Y.: Análisis de los deslizamientos en la cuenca de la Quebrada La Iguaná de la ciudad de Medellín a partir de la interacción lluvia-pendiente-formación geológica, Revista DYNA, 142, 33-45, 2004 (in Spanish).

ERM-Hong Kong, Ltd.: Landslides and boulder falls from natural terrain: interim risk guidelines, ERM-Hong Kong, Ltd, Hong Kong, Geo Report No. 75, 184 pp., 1998.

Flórez, M. A.: Movimientos en masa: Identificación, causas y alternativas de manejo en Medellín, Alcaldía de Medellín, 2003 (in Spanish).

Fell, R., Corominas, J., Bonnard, Ch., Cascini, L., Leroi, E., and Savage, W. Z.: Guidelines for landslide susceptibility, hazard and risk zoning for land use planning, Eng. Geol., 102, 85-98, 2008.

Glade, T. and Crozier, M. J.: The nature of landslide hazard impact, in: Landslide Hazard and Risk, edited by: Glade, T., Anderson, M., and Crozier, M. J., Wiley, Chichester, 43-74, 2005.

GSM (Grupo Sismológico de Medellín): Instrumentación y microzonificación sísmica del área urbana de Medellín, Municipio de Medellín - Sistema Municipal de Prevención y Atención de Desastres, 1999 (in Spanish).

Guinau, M., Pallás, R., and Vilaplana, J. M.: A feasible methodology for landslide susceptibility assessment in developing countries: A case-study of NW Nicaragua after Hurricane Mitch, Eng. Geol., 80, 316-327, 2005.

Guzzetti, F., Carrara, A., Cardinali, M., and Reichenbach, P.: Landslide hazard evaluation: a review of current techniques and their application in a multi-scale study, Central Italy, Geomorphology, 31, 181-216, 1999.

Hormanza, M. A.: Investigación preliminar de las causas probables de deslizamientos en las laderas de Medellín, M.Sc. thesis, Universidad Nacional de Colombia, Medellín, 259 pp., 1991 (in Spanish).

INGEOMINAS: Catálogo Nacionál de Movimientos en Masa, Subdirección de Amenazas Geoambientales, Bogotá, 2002 (in Span- 
ish).

INGEOMINAS: Mapa de grandes terremotos de Colombia 15661999, available at: http://tms.ingeominas.gov.co/web/2004/ mapas2/GrandesSismos/index.html, last access: 5 January 2010 (in Spanish).

INGEOMINAS: Mapa de Sismicidad de Colombia, available at: http://tms.ingeominas.gov.co/web/2004/mapas2/ MapaSismicidad/index.html, last access: 5 January 2010 (in Spanish).

Malamud, B. D., Turcotte, D. L., Guzzetti, F., and Reichenbach, P.: Landslide inventories and their statistical properties, Earth Surf. Proc. Land., 29, 687-711, 2004.

Montoya, J. J. and Patiño, J. E.: Estudio hidrometeorológico y geomorfológico de diez quebradas del Valle de Medellín, M.Sc. thesis, Universidad EAFIT, Medellín, 102, 2001 (in Spanish).

Mora, S. and Keipi, K.: Disaster risk management in development projects: models and checklists, B. Eng. Geol. Environ., 65, 155165, 2006.

Moreno, H. A., Vélez, M. V., Montoya, J. D., and Rhenals, R. L.: La lluvia y los deslizamientos de tierra en Antioquia: Análisis de su ocurrencia en las escalas interanual, intraanual y diariaj, Revista EIA, 5, 59-69, 2006 (in Spanish).

Nadim, F., Kjekstad, O., Peduzzi, P., Herold, C., and Jaedicke, C.: Global landslide and avalanche hotspots, Landslides, 3, 159173, 2006.

Ojeda, J. and Muñoz, F.: Elementos conceptuales generales, in: Evaluación de riesgos por fenómenos de remoción en masa, edited by: Lemoine, J., INGEOMINAS, CVC and ECI, Bogotá, Colombia, 17-28, 2001 (in Spanish).

Planeación Municipal: Plan de Ordenamiento Territorial del Municipio de Medellín, Medellín, Acuerdo 69 de 1999, 1999 (in Spanish).
Poveda, G., Mesa, O. J., Salazar, L. F., Arias, P. A., Moreno, H. A., Vieira, S. C., Agudelo, P. A., Toro, V. G., and Alvarez, J. F.: The diurnal cycle of precipitation in Tropical Andes of Colombia, Mon. Weather Rev., 133, 228-240, 2005.

Rendón, D. A.: Cartografía y caracterización de las unidades geológicas de la zona urbana de Medellín, B.c. thesis, Universidad Nacional de Colombia, Medellín, 290 pp., 1999 (in Spanish).

Rendón, D. A.: Tectonic and sedimentary evolution of the upper Medellín Valley, northern Colombian Andes, M.S. thesis, Shimane University, Colombia, 113 pp., 2003 (in Spanish).

Restrepo, J. J. and Toussaint, J. F.: Unidades litológicas de los alrededores de Medellín, in: Proceedings of the Conferencia sobre riesgos geológicos del Valle de Medellín, Memorias, 1-26, 1984.

Rosenfeld, C. L.: The geomorphological dimensions of natural disasters, Geomorphology, 10, 27-36, 1994.

Rybář, J.: Rozbor příčin zvýšeného výskytu svahových deformací v České republice v červenci 1997, Geotechnika, 2, 7-14, 1999 (in Czech).

Saldarriaga, R.: Inventario y Sistematización de los Desastres Naturales reportados en los municipios del Valle de Medellín, entre los años 1900 y 2002, M.S. thesis, Universidad EAFIT, Medellín, Colombia, 120 pp., 2003 (in Spanish).

Toro, G. and Velázquez, A.: Estudio geomorfológico y estructural del Valle de Medellín: comprendido entre el municipio de Caldas y las quebradas la iguana y Santa Elena, M.S., Universidad Nacional de Colombia Medellín, Medellín, 210 pp., 1984 (in Spanish).

Van Westen, C. J., van Asch, T. W. J., and Soeters, R.: Landslide hazard and risk zonation - why is it still so difficult?, B. Eng. Geol. Environ., 65, 167-184, 2006. 